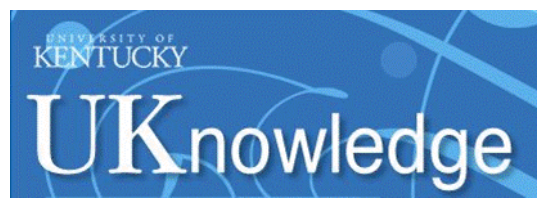

University of Kentucky

UKnowledge

Fall 2011

\title{
The Gray Lady's Guide to Avant-Garde Cinema
}

Brian L. Frye

University of Kentucky College of Law, brianlfrye@uky.edu

Follow this and additional works at: https://uknowledge.uky.edu/law_facpub

Part of the Film and Media Studies Commons

Right click to open a feedback form in a new tab to let us know how this document benefits you.

\section{Recommended Citation}

Brian L. Frye, The Gray Lady's Guide to Avant-Garde Cinema, INCITE J. Experimental Media, no. 3, Fall 2011, at 54 .

This Article is brought to you for free and open access by the Law Faculty Publications at UKnowledge. It has been accepted for inclusion in Law Faculty Scholarly Articles by an authorized administrator of UKnowledge. For more information, please contact UKnowledge@lsv.uky.edu. 


\section{The Gray Lady's Guide to Avant-Garde Cinema}

Notes/Citation Information

INCITE Journal of Experimental Media, No. 3 (Fall 2011), pp. 54-65 


\section{THE GRAY LADY'S GUIDE TO AVANT- GARDE CINEMA Brian L. Frye}

The only thing worse than being talked about is not being talked about.

- Oscar Wilde

\section{INTRODUCTION}

Who is the most important avant-garde filmmaker? It depends who you ask. Different people value different things at different times. Fortunately, citation analysis can provide an objective answer. This article uses a citation study of The New York Times to measure the relative importance of avant-garde filmmakers. It concludes that, according to The New York Times, the most important avant-garde filmmaker is Andy Warhol.

\section{RATIONALE}

\section{A. What is Citation Analysis?}

Citation analysis, or the study of citation frequency, is a common bibliometric tool. Citation studies measure the importance of scholarly articles according to the frequency of their citation in other articles. ${ }^{1}$ While scholars cite articles for many different reasons, they usually cite articles that are relevant to their own scholarship. 
Citation studies assume that scholars frequently cite important articles and infrequently cite unimportant articles. They count the number of times that particular articles are cited by other articles. They conclude that frequently cited articles are more important and less frequently cited articles are less important. The result is an objective measurement of the relative importance of the articles.

\section{B. Problems \& Solutions}

While citation analysis is a useful tool, citation studies have three potential weaknesses: misleading citations, under-citation, and corrupted data. ${ }^{2}$ Fortunately, it is easy to minimize these weaknesses or even avoid them entirely.

Misleading citations occur when scholars cite articles for reasons that do not support an inference of importance. For example, self-citation and negative citation do not necessarily reflect importance. Self-citation may artificially inflate the number of citations to an article. Negative citation may result in a large number of citations to an unimportant article.

Neither self-citation nor negative citation is likely to affect the accuracy of a robust citation study. Self-citation can only produce a small number of additional citations, so it cannot affect the accuracy of a large citation study. Negative citation is unlikely to affect the accuracy of a citation study because a large number of negative citations also suggest that an article is important, but controversial.

Under-citation occurs when an influential article becomes part of the scholarly vernacular and no longer requires a citation. Under-citation is unlikely to affect the accuracy of a citation study because an article must receive many citations before citation becomes unnecessary. 
Third, the data used in a citation study may be inaccurate or incomplete. Inaccuracies are minimized by careful compilation and analysis of the data. A transparent methodology can demonstrate the completeness of the dataset.

\section{Why Citation Analysis?}

Citation analysis is an effective method of measuring the relative importance of avant-garde filmmakers because it is more accurate and more objective than alternative methods. Measuring the importance of avant-garde filmmakers is hard because it is hard to define and measure the qualities that make an avant-garde filmmaker important.

Measurements of the relative importance of avant-garde filmmakers usually rely on aesthetic criteria, which are inherently subjective and difficult to quantify. For example, film critics generally rely on aesthetic criteria when they evaluate the importance of an avant-garde film or filmmaker. In other words, they praise films they like and condemn films they do not like.

Not only is the film criticism method of evaluation highly subjective, but also the accuracy of the data produced is questionable. ${ }^{3} \quad$ Film critics frequently disagree ${ }^{4}$ and false positives may be a problem. ${ }^{5}$ While many film critics do provide quantifiable data, often in the form of numerical "star ratings," this data suffers the same weaknesses, as it still reflects an aesthetic judgment.

Sometimes, film critics rank filmmakers in order of preference, often in form of "top tens" or "top 100s." 6 While these rankings may provide some indication of the aesthetic criteria a critic considers relevant, they also suffer from the inherent weaknesses of the film criticism method. According to Condorcet's Jury Theorem, 
averages of many such rankings may increase their accuracy, but probably only amplifies their weaknesses?

The relative importance of films and filmmakers can be measured in financial terms. For example, lists of "highest grossing films" 8 and "highest grossing directors"9 arguably reflect the relative importance of the films and directors they list. However, a financial analysis is unlikely to accurately measure the relative importance of avant-garde filmmakers because avant-garde films are exchanged primarily within an academic gift economy, in which compensation is generally non-monetary.10 "[F]ar from relying on growth of capital and success in the marketplace, the avantgarde filmmaker focuses on acquiring something called symbolic capital and manipulates this to achieve fame and success in the community."

By contrast, citation analysis is an empirical method that relies on clearly defined, relevant, and objective criteria. Citations are easy to identify and quantify. A citation occurs every time an article, film, or filmmaker is mentioned. Citations are the most relevant metric for an academic gift economy like avant-garde film because reputation is the currency of choice. And citations are objective because they do not reflect aesthetic preference or any other subjective criteria.

\section{METHODOLOGY}

This article uses a citation study of The New York Times to measure the relative importance of 22 avant-garde filmmakers. The citation study counts the number of times that the name of each filmmaker appears in The New York Times between 1940 and 2007. Accordingly, the citation study determines the relative importance of the filmmakers, according to The New York Times. 
The source of the data used for the citation study was the ProQuest Historical New York Times database, a searchable database that includes every issue of The New York Times printed from 1851 to 2007.12 The New York Times, or "Gray Lady," is generally considered the American newspaper of record. It purports to present, "All the News That's Fit to Print." Accordingly, it covers every motion picture film that opens in New York and covers most significant art events occurring in New York. The New York Times covers everything it considers important, so a mention of a filmmaker means that it considers that filmmaker important.

An "avant-garde filmmaker" is a person who makes avant-garde films, a genre of films loosely defined by certain qualities. ${ }^{13}$ Essentially, avant-garde films are addressed to a fine art audience, rather than a popular audience.

The list of avant-garde filmmakers used in this citation study was drawn from the Essential Cinema Repertory, a list of films selected in 1970-75 by the Anthology Film Archives Film Selection Committee. ${ }^{14}$ The Essential Cinema Repertory includes 330 films by 84 filmmakers. ${ }^{15}$ It was intended "to define the art of cinema" and includes many different kinds of films, including avant-garde films. ${ }^{16}$

This citation study considers only 22 of the 84 filmmakers represented in the Essential Cinema Repertory. Many of the Essential Cinema filmmakers are not avantgarde filmmakers. Some avant-garde filmmakers rarely appear in The New York Times. This citation study considers only Essential Cinema filmmakers who are avant-garde filmmakers and who appear in The New York Times with some frequency. 
I determined the citation count for each filmmaker by searching the Historical New York Times database for that filmmaker's name. I also recorded the number of citations to each filmmaker by decade. As indicated in Table I, I modified certain searches in order to eliminate false positives and maximize the accuracy of the citation counts. I also eliminated any citation that predated a filmmaker's first film.

Table II presents the results of the citation study. It lists each filmmaker's citations by decade, followed by the total number of citations. It shows that The New York Times most-cited filmmaker is Andy Warhol, by an overwhelming margin. The next most-cited filmmakers are Jonas Mekas and Stan Brakhage, who both received about $25 \%$ as many cites as Warhol.

Table II also reveals trends in the citation of certain filmmakers, which presumably reflect changes in their relative importance. For example, some filmmakers received fewer citations over time, suggesting that their importance diminished, while some filmmakers received more citations over time, suggesting that their importance increased. Interestingly, Jack Smith received many citations in the 1960s, fewer citations in the 1970s and 1980s, and many citations in the 1990s and 2000s. Apparently, Smith's importance declined in the 1970s and 1980s, but increased again in the 1990s and 2000s.

Many filmmakers received fewer citations in the 1980s, suggesting that the importance of avant-garde film as a genre decreased during that time. However, the overall number of citations has rebounded, so the genre must be important once again. 
A decrease in citations during the 1980 s is common to most of the filmmakers studied. However, not all of the filmmakers received a larger number of citations in the 1990s and 2000s. It appears that some filmmakers became more important over time and some filmmakers became less important over time.

\section{CONCLUSION}

According to the The New York Times, Andy Warhol is the most important avantgarde filmmaker. Other important avant-garde filmmakers are Jonas Mekas and Stan Brakhage. The importance of some avant-garde filmmakers has waxed and waned over time.

\section{NOTES}

1. See Fred R. Shapiro, "The Most-Cited Law Review Articles," 73 Cal. L. Rev. 1540 (1985); see also J.M. Balkin \& Sanford Levinson, How to Win Cites and Influence People, 71 Chi.-Kent L. Rev. 843 (1996).

2. Linda C. Smith, "Citation Analysis," 30 Library Trends 83 (1981).

3. Nevertheless, the author concedes a certain weakness for this method of evaluation. See Brian Frye, "Bob le fambeur," Senses of Cinema (2003), http://archive.sensesofcinema.com/contents/cteq/03/25/bob_le_flambeur.html.

4. See David Madison, "The 10 Most Polarizing Movies of the Last Decade," Unreality Magazine (June 11, 2009), hitp://unrealitymag.com/index.php/2009/06/11/the-10most-polarizing-movies-of-the-last-decade/.

5. See Coury Turczyn, "This Week: Movie Critics Who Will Shill for Anything!," PopCult Magazine (March 28, 2002), http://www.popcultmag.com/passingfancies/bottomfive/ moviecritics/moviecritics 1.html.

6. See "Top Tens," Senses of Cinema, http://archive.sensesofcinema.com/contents/ top_tens/.

7. See "Avant-garde Poll," Film Comment (May-June 2010), hitp://www.filmlinc.com/ $\mathrm{fcm} / \mathrm{mj} 10 /$ agpoll.htm. 
8. See "Worldwide Grosses," http://www.boxofficemojo.com/alltime/world/; "Domestic Grosses Adjusted for Inflation," hitp://boxofficemojo.com/alltime/adjusted. htm?adjust_yr=1910\&p=.hrm.

9. See "Most Profitable Directors of All Time," at http://www.slashfilm. com/2008/01/02/most-profitable-directors-of-all-time/.

10. See Tyler Cowen \& Alexander Tabarrok, "An Economic Theory of Avant-Garde and Popular Art, or High and Low Culture," 67 So. Econ. J. 232 (2000); Cf. David J. Cheal, The Gift Economy (New York: Routledge, 1988).

11. Kathryn Ramey, "Economics of the Film Avant-Garde: Networks and Strategies in the Circulation of Films, Ideas, and People," Jump Cut 52 (Summer 2010), http://www. ejumpcut.org/currentissue/rameyExperimentalFilm/index.html.

12. ProQuest Historical Newspapers, available at http://www.proquest.com/en-US/ catalogs/databases/detail/pq-hist-news.shtml.

13. Fred Camper, "Naming, and Defining, Avant-Garde or Experimental Film," http:// www.fredcamper.com/Film/AvantGardeDefinition.html.

14. "About / Essential Cinema," Anthology Film Archives website, http://anthologyfilmarchives.org/about/essential-cinema. The Film Selection Committee consisted of James Broughron, Ken Kelman, Peter Kubelka, P. Adams Sitney, and Jonas Mekas. 15. The filmmakers represented in the Essential Cinema Repertory are: James Agee, Kenneth Anger, Bruce Baillie, Jordan Belson, Stan Brakhage, Robert Bresson, James Broughton, Luis Buñuel, Alberto Cavalcanti, Charles Chaplin, Rene Clair, Jean Cocteau, Bruce Conner, Tony Conrad, Joseph Cornell, Douglas Crockwell, Maya Deren, Alexandr Dovzhenko, Carl Th. Dreyer, Marcel Duchamp, Viking Eggeling, Sergei Eisensiein, Jean Epstein, Lovis Fevillade, Robert Flaherty, Bob Fleischner, Hollis Frampton, Georges Franju, Robert Frank, Jean Genet, D. W. Griffith, Alexander Hammid, Marcel Hanoun, Jerome Hill, lan Hugo, Ken Jacobs, Humphrey Jennings, Larry Jordan, Buster Keaton, Dimitri Kirsanoff, Peter Kubelka, Mike Kuchar, George Kuchar, George Landow, Fernand Leger, Alfred Leslie, Helen Levitt, Janice Loeb, Louis Lumiere, Augusłe Lumiere, Len Lye, Willard Maas, Christopher MacLaine, Gregory Markopoulos, Jonas Mekas, Georges Melies, Marie Menken, F. W. Murnau, Dudley Murphy, Robert Nelson, Yasujiro Ozu, Sidney Peterson, Francis Picabia, Vsevolod Pudovkin, Man Ray, Jean Renoir, Ron Rice, Hans Richter, Leni Riefenstahl, Roberto Rossellini, Walther Ruttmann, Paul Sharits, Harry Smith, Jack Smith, Michael Snow, Erich von Stroheim, Karl Valentin, Dziga Vertov, Jean Vigo, Andy Warhol, John Sibley, Melville Watson Webber, Orson Welles, James Whitney, and John Whitney.

16. "About / Essential Cinema," Anthology Film Archives website, http://anthologyfilmarchives.org/about/essential-cinema. 


\section{TABLE I: SEARCH MODIFICATIONS}

\begin{tabular}{|l|l|}
\hline FILMMAKER & MODIFICATION \\
\hline Kenneth Anger & None \\
\hline Bruce Baillie & None \\
\hline Stan Brakhage & None \\
\hline Bruce Conner & $<$ <and $>$ film \\
\hline Joseph Cornell & \\
\hline Maya Deren & $<$ and $>$ film \\
\hline Hollis Frampton & None \\
\hline Ken Jacobs & None \\
\hline Larry Jordan & \\
\hline Peter Kubelka & Nand $>$ film \\
\hline
\end{tabular}




\begin{tabular}{|l|l|}
\hline FILMMAKER & MODIFICATION \\
\hline Mike Kuchar & Mike <within 3> Kuchar \\
\hline George Landow / Owen Land & None \\
\hline Christopher Maclaine & None \\
\hline Gregory Markopoulos & None \\
\hline Jonas Mekas & None \\
\hline Marie Menken & \\
\hline Carolee Schneemann & None \\
\hline Paul Sharits & None \\
\hline Jack Smith & None \\
\hline Michael Snow & \\
\hline & $<$ and $>$ film \\
\hline & \\
\hline & \\
\hline
\end{tabular}




\section{TABLE II: CITATION STUDY}

\begin{tabular}{|l|c|c|c|}
\hline FILMMAKER & $\mathbf{1 9 4 0 - 4 9}$ & $\mathbf{1 9 5 0 - 5 9}$ & $\mathbf{1 9 6 0 - 6 9}$ \\
\hline Anger, Kenneth & 0 & 5 & 56 \\
\hline Baillie, Bruce & 0 & 0 & 7 \\
\hline Brakhage, Stan & 0 & 8 & 45 \\
\hline Conner, Bruce & 0 & 0 & 9 \\
\hline Cornell, Joseph & 1 & 0 & 0 \\
\hline Deren, Maya & 16 & 30 & 12 \\
\hline Frampton, Hollis & 0 & 0 & 0 \\
\hline Jacobs, Ken & 0 & 0 & 9 \\
\hline Jordan, Larry & 0 & 0 & 3 \\
\hline Kubelka, Peter & 0 & 0 & 3 \\
\hline Kuchar, George & 0 & 0 & 6 \\
\hline Kuchar, Mike & 0 & 0 & 12 \\
\hline Landow, George & 0 & 0 & 4 \\
\hline Maclaine, Christopher & 0 & 0 & 0 \\
\hline Markopoulos, Gregory & 0 & 1 & 8 \\
\hline Mekas, Jonas & 0 & 3 & 81 \\
\hline Menken, Marie & 0 & 5 & 12 \\
\hline Schneeman, Carolee & 0 & 0 & 8 \\
\hline Sharits, Paul & 0 & 0 & 2 \\
\hline Smith, Jack & 0 & 0 & 17 \\
\hline Snow, Michael & 0 & 5 \\
\hline Warhol, Andy & 0 & 1 & \\
\hline & 0 & & \\
\hline
\end{tabular}




\begin{tabular}{|c|c|c|c|c|}
\hline $1970-79$ & $1980-89$ & $1990-99$ & $2000-07$ & TOTAL \\
\hline 31 & 42 & 32 & 44 & 210 \\
\hline 7 & 2 & 8 & 0 & 24 \\
\hline 31 & 53 & 80 & 86 & 303 \\
\hline 6 & 7 & 13 & 4 & 39 \\
\hline 5 & 16 & 31 & 16 & 69 \\
\hline 17 & 31 & 37 & 59 & 202 \\
\hline 22 & 22 & 10 & 5 & 59 \\
\hline 17 & 20 & 30 & 33 & 109 \\
\hline 10 & 5 & 10 & 7 & 35 \\
\hline 9 & 5 & 5 & 5 & 27 \\
\hline 18 & 23 & 23 & 14 & 84 \\
\hline 10 & 9 & 4 & 7 & 42 \\
\hline 5 & 10 & 9 & 5 & 33 \\
\hline 0 & 2 & 3 & 0 & 5 \\
\hline 1 & 0 & 6 & 1 & 17 \\
\hline 104 & 28 & 60 & 56 & 332 \\
\hline 7 & 3 & 7 & 6 & 43 \\
\hline 3 & 2 & 3 & 8 & 24 \\
\hline 11 & 4 & 11 & 5 & 33 \\
\hline 5 & 9 & 32 & 18 & 81 \\
\hline 15 & 7 & 15 & 19 & 61 \\
\hline 141 & 344 & 420 & 163 & 1219 \\
\hline
\end{tabular}

